\title{
RESPONSE OF IN-939 TO PROCESS VARIATIONS
}

\author{
S.W.K. Shaw \\ Inco, European R. and D. Centre, Birmingham B16 OAJ.
}

The development of the 4-stage heat treatment for the cast corrosion-resistant superalloy IN-939 is described. The effects on properties and structures of the various stages of heat treatment are reviewed und properties achievable for a $4 h / 1160^{\circ} \mathrm{C}+$ $6 \mathrm{~h} / 1000^{\circ} \mathrm{C}$ treatment, recommended for vane applications are provided. Cooling rate during heat treatment is shown to have a marked effect on some properties and grain boundary structure; properties are given for a simple heat treatment of $4 \mathrm{~h} / 1160^{\circ} \mathrm{C}+$ $16 \mathrm{~h} / 850^{\circ} \mathrm{C}$, cooling at $50 \mathrm{C} / \mathrm{min}$. Remarkable repair weldability, with the possibility of further improvement from increased ductility achieved by overaging in the eta phase range is noted and improved properties in DS castings with and without Hf additions are reported.

\section{INTRODUCTION}

IN-939 was developed to meet the need for a highly corrosion-resistant, cast, nicke1-based superalloy for the blades and vanes of industrial and marine gas turbines (1) (2). The alloy has the chemical composition $\mathrm{Ni}-22.5 \% \mathrm{Cr}-19 \% \mathrm{Co}-$ $2 \% \mathrm{~W}-1 \% \mathrm{Nb}-1.4 \% \mathrm{Ta}-3.7 \% \mathrm{Ti}-1.9 \% \mathrm{~A} 1-0.15 \% \mathrm{C}-0.1 \% \mathrm{Zr}-0.01 \% \mathrm{~B}$. Because of the relatively high chromium content, IN-939 is several times more corrosion resistant than IN-738LC $(16 \% \mathrm{Cr})$; creeprupture stresses are at least as high as for $1 \mathrm{~N}-738 \mathrm{LC}$ for $>10,000$ hours life (3). In assessments for vane applications, the alloy has proved as corrosion resistant as the cobalt-based alloy FSX-414 (29.5\%Cr), and has a surprising degree of repair weldability. IN-939 has been in commercial production and use since 1974, but work has continued on the alloy's response to variations in processing, in particular casting conditions, heat-treatment and welding. This paper describes the effects of heat treatment on properties and structure, the response to welding and the infiluence of unidirectional solidification on IN-939. 


\section{DEVELOPMENT OF 4-STAGE HEAT TREATMENT}

The heat treatment used during the compositional development of IN-939 was full solution treatment for $4 \mathrm{~h} /$ $1150^{\circ} \mathrm{C}\left(2100^{\circ} \mathrm{F}\right)$, followed by ageing for $16 \mathrm{~h} / 850^{\circ} \mathrm{C}\left(1560^{\circ} \mathrm{F}\right)$. During the final stages of optimising the composition a para11e1 study of heat treatment was undertaken on a $15 \% \mathrm{Co}$, $3.5 \% \mathrm{Ti}$ alloy, otherwise identical to the IN-939 composition. Development of a better heat treatment seemed necessary because the simple twostage treatment gave very poor roomtemperature tensile ductility ( $0.7 \%$ elongation) and marginal stress-rupture ductility.

The stratagem used to achieve good properties in IN-738, a partial solution treatment to produce coarse $\gamma^{\prime}$ and a single age to precipitate fine $\gamma^{\prime}$, did not work for the $15 \%$ Co-3.5\% Ti alloy because $\eta$ phase precipitated at temperatures suitable for partial solution of $\gamma^{\prime}$. Nor was the four-stage heat treatment developed for Udimet 700 satisfactory: stress-rupture life was poor and there was no improvement in tensile ductility. However, when the temperature of the first age in that treatment was reduced from $1080^{\circ} \mathrm{C}$ to $1000^{\circ} \mathrm{C}$, formation of $\eta$ phase was avoided and both tensile and rupture ductility improved somewhat. A further improvement resulted from decreasing the temperatures of the third and fourth stage ageing treatments, but attempts to reduce the length and cost of treatment by omitting one stage or combining two stages at an intermediate temperature failed: a11 such treatments produced inferior slress-rupture life and omlssion of $6 \mathrm{~h} / 1000^{\circ} \mathrm{C}$ gave inadequate tensile ductility (4).

When the final composition of IN-939 was chosen, the four-stage heat treatment which gave the best properties in the $15 \mathrm{Co}-3.5 \mathrm{Ti}$ alloy and the original simple two-stage treatment were compared using IN-939. Again, the fourstage treatment gave bctter room-temperature tensile ductility, $3.0-3.8 \%$ compared with $0.5-0.7 \%$ from the two stage treatment, and better elevated temperature tensile and stress-rupture ductility. Therefore, for the standard heat treatment of IN-939 to yield the best combination of properties, it was decided to recommend a four-stage treatment, namely:

$$
4 \mathrm{~h} / 1160^{\circ} \mathrm{C}+6 \mathrm{~h} / 1000^{\circ} \mathrm{C}+24 \mathrm{~h} / 900^{\circ} \mathrm{C}+16 \mathrm{~h} / 700^{\circ} \mathrm{C} \text {. }
$$

The first stage of this treatment takes all the $\gamma^{\prime}$ and practically all the $\eta$ phase into solution and achieves significant homogenisation. The first age, at $1000^{\circ} \mathrm{C}$, grows 
the $\gamma^{\prime}$ particles formed on cooling after solution treatment and precipitates a small amount of carbide on the grain boundaries. The second age, at $900^{\circ} \mathrm{C}$, probably causes some further growth of the $\gamma^{\prime}$ particles and is responsible for major strengthening at the grain boundaries by precipitation of discrete particles of $\mathrm{M}_{23} \mathrm{C}_{6}$. The final age, at $700^{\circ} \mathrm{C}$, precipitates fine secondary $\gamma^{\prime}$ particles, only about $100 \AA$ in diameter, markedly increasing the proof stress at ambient and intermediate temperatures (5).

\section{FURTHER STUDY OF HEAT TREATMENT}

Although the four-stage heat treatment adopted for IN-939 provides an excellent combination of properties, 50 hours at temperature are needed, plus heating and cooling time. Consequently, a shorter and cheaper heat treatment has been sought, by a combination of empirical experiments with a study of the effect of the various stages of treatment on mechanical properties and structure.

Solution Treatment

Incomplete solution of $\eta$-phase, reported from a commercial vacuum heat treatment of large vanes, led to an investigation into the effect on mechanical properties of variations in solution treatment temperature between 1090 and $1210^{\circ} \mathrm{C}$ (Table 1). Poor stress-rupture properties were obtained under all test conditions, after 4-stage heat treatment involving solution treatment at $1090^{\circ} \mathrm{C}$, at which temperature substantial amounts of $\gamma^{\prime}$ and $\eta$ phase remain undissolved. After solution treatment at $1120^{\circ} \mathrm{C}$, the critical longer-time rupture 1 ife was unsatisfactory, although life in the shorter-time tests was surprisingly good. The high room-temperature $0.2 \%$ proof stress suggests that solution of $\gamma^{\prime}$ is almost complete at $1120^{\circ} \mathrm{C}$. In this set of results, solution treatment at $1150^{\circ} \mathrm{C}$ gave the best results although even after $1180^{\circ} \mathrm{C}$ treatment a life of $1832 \mathrm{~h}$ was recorded. Tensile $0.2 \%$ proof stresses were a little lower and elongations marginally higher with $1160^{\circ} \mathrm{C}$ to $1180^{\circ} \mathrm{C}$ solution treatment than with $1150^{\circ} \mathrm{C}$. With $1210^{\circ} \mathrm{C}$ treatment, the rupture lives plunged to low values with the onset of incipient melting at grain corners and in grain boundaries. These results, reinforced by metallographic evidence on the solution of $\eta$ phase in block samples cut from the root block of a large vane, suggested that solution treatment temperature should be no fower than $1145^{\circ} \mathrm{C}$; to allow a margin of error of at least $-15^{\circ} \mathrm{C}$ in large commercial vacuum furnaces, it was decided that the recommended temperature should be $1160^{\circ} \mathrm{C}$. 
Short time stress-rupture properties were used to determine the effect of varying the temperature of the primary $\gamma^{\prime}$ precipltation treatment between $980^{\circ} \mathrm{C}$ and $1030^{\circ} \mathrm{C}$, while keeping the other three heat-treatment stages unchanged. Stress-rupture life at $247 \mathrm{~N} / \mathrm{mm}^{2} / 900^{\circ} \mathrm{C}$ varied only between 49 and 60 hours, although $\gamma^{\prime}$ size increased from 1620 to $2510 \AA$ as ageing temperature was increased over the $50^{\circ} \mathrm{C}$ range. It was concluded that a practical specification of $1000^{\circ} \mathrm{C}-15^{\circ} \mathrm{C}$ was satisfactory.

Omitting the $1000^{\circ} \mathrm{C}$ age raised $0.2 \%$ proof stress and short-time stress-rupture life (at $379 \mathrm{~N} / \mathrm{mm}^{2} / 816^{\circ} \mathrm{C}$ ) but, as expected from the earlier work on the $15 \% \mathrm{Co}-3.5 \% \mathrm{Ti}$ alloy, decreased long-time stress rupture life (at $276 \mathrm{~N} / \mathrm{mm}^{2} / 816^{\circ} \mathrm{C}$ ) and markedly reduced tensile ductility (Table 2). Restricting

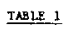

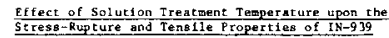

\begin{tabular}{|c|c|c|c|c|c|c|c|c|}
\hline \multirow{2}{*}{\multicolumn{2}{|c|}{ Test Cond 1 tons }} & \multicolumn{7}{|c|}{ Solution Treatment -4 Hours ${ }^{\dagger}$} \\
\hline & & 1090 & 1120 & 1150 & 1160 & 1170 & 1180 & 1210 \\
\hline \multicolumn{9}{|c|}{ St ress-Rupture } \\
\hline $\begin{array}{l}\text { Stregs } \\
\text { N/tom }{ }^{7}\end{array}$ & $\underset{C}{T}{ }_{C}$ & \multicolumn{7}{|c|}{$11 \%-h$} \\
\hline$\stackrel{276}{" 10}$ & 816 & 570 & $\begin{array}{l}x 112 \\
1052\end{array}$ & $\begin{array}{l}2057 \\
1899\end{array}$ & 1726 & - & $\begin{array}{l}1832 \\
1404\end{array}$ & 791 \\
\hline "350 & $"$ & $\begin{array}{l}148 \\
130\end{array}$ & $\begin{array}{l}524 \\
416\end{array}$ & $\begin{array}{l}690 \\
586\end{array}$ & $\begin{array}{l}635 \\
570\end{array}$ & $\begin{array}{l}629 \\
427\end{array}$ & $\begin{array}{l}444 \\
320\end{array}$ & $\begin{array}{l}276 \\
250\end{array}$ \\
\hline 379 & $"$ & $\begin{array}{l}21 \\
13\end{array}$ & $\begin{array}{l}207 \\
209\end{array}$ & $\begin{array}{l}212 \\
198\end{array}$ & 173 & $\begin{array}{l}164 \\
143\end{array}$ & $\begin{array}{r}140 \\
97\end{array}$ & $\begin{array}{l}46 \\
46\end{array}$ \\
\hline 120 & 927 & 328 & 623 & 902 & 753 & 646 & 574 & 221 \\
\hline \multicolumn{9}{|c|}{$2 n^{*} C$ - Terisste Properties } \\
\hline \multirow[t]{2}{*}{$\mathrm{N} / \mathrm{man}^{2}$} & $0.2 \mathrm{~m}$ & $\begin{array}{l}687 \\
677\end{array}$ & $\begin{array}{l}782 \\
738\end{array}$ & $\begin{array}{l}807 \\
783\end{array}$ & $\begin{array}{l}758 \\
745\end{array}$ & $\begin{array}{l}787 \\
748\end{array}$ & $\begin{array}{l}750 \\
736\end{array}$ & $\begin{array}{l}768 \\
754\end{array}$ \\
\hline & ข. T. $\mathrm{s}$. & $\begin{array}{l}803 \\
899\end{array}$ & $\begin{array}{l}978 \\
901\end{array}$ & $\begin{array}{l}967 \\
919\end{array}$ & $\begin{array}{l}981 \\
939\end{array}$ & $\begin{array}{l}968 \\
926\end{array}$ & $\begin{array}{l}928 \\
824\end{array}$ & $\begin{array}{l}951 \\
951\end{array}$ \\
\hline \multirow{2}{*}{2} & Elong. & $\begin{array}{l}1.6 \\
4.4\end{array}$ & $\begin{array}{l}4.3 \\
2.1\end{array}$ & $\begin{array}{l}3.9 \\
2.4\end{array}$ & $\begin{array}{l}4.0 \\
3.9\end{array}$ & $\begin{array}{l}3.6 \\
3.9\end{array}$ & $\begin{array}{l}4.7 \\
3.1\end{array}$ & $\begin{array}{l}3.6 \\
2.4\end{array}$ \\
\hline & R. of $\mathrm{A}$. & 4.7 & 8.5 & 14.5 & 7.8 & 7.8 & 8.5 & 11.6 \\
\hline
\end{tabular}

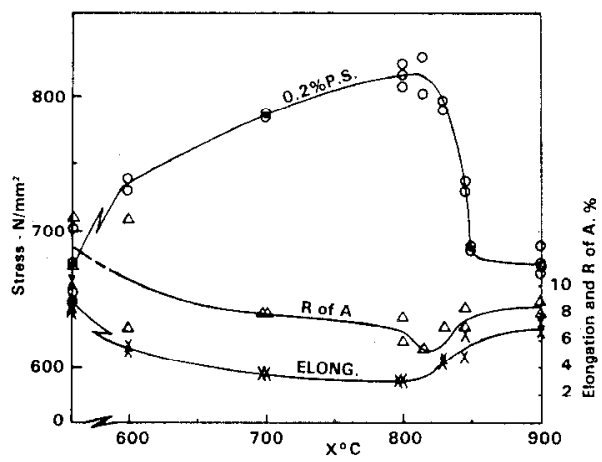

Figure 1. Hoom Temparature Tensile Propertios of IN 939 Heat Treated $4 \mathrm{~h} / 1160^{\circ} \mathrm{C}+6 \mathrm{~h} / 1000^{\circ} \mathrm{C}+$ $16 \mathrm{~h} / \mathrm{x}^{\circ} \mathrm{C}$ Air Cooled.

TABLE 2

Creep-Rupture and Tens11e Propert1es of IN-939 uth Varlous Stages of the 4 Stage Heat Treatment Om1tted

\begin{tabular}{|c|c|c|c|c|c|c|c|c|c|c|c|c|c|}
\hline \multirow{2}{*}{\multicolumn{4}{|c|}{ Heat Tratwent (Stages) }} & \multicolumn{6}{|c|}{ Stress-Rupture } & \multicolumn{4}{|c|}{ Tensile $-20^{\circ} \mathrm{C}$} \\
\hline & & & & \multicolumn{2}{|c|}{$379 \mathrm{~N} / \mathrm{mm}^{2} / 816^{\circ} \mathrm{C}$} & \multicolumn{2}{|c|}{$330 \mathrm{~N} / \mathrm{mm}^{2} / 816^{\circ} \mathrm{C}$} & \multicolumn{2}{|c|}{$276 \mathrm{~N} / \mathrm{mm}^{2} / 816^{\circ} \mathrm{C}$} & \multicolumn{2}{|l|}{$\mathrm{N} / \mathrm{mm}^{2}$} & \multicolumn{2}{|c|}{$z$} \\
\hline $1 s t$ & $2 n d$ & $3 \mathrm{rd}$ & $4 \mathrm{th}$ & Lite $n$ & ELong. $z$ & L1te $\mathrm{n}$ & ELlong. $z$ & Wite $\mathrm{h}$ & Elong. $\pi$ & $0.2 \% 58$ & U. T.S. & Elong. & R. of A. \\
\hline $4 / 1150$ & $6 / 1000$ & $24 / 900$ & $16 / 700$ & $\begin{array}{l}174 \\
108\end{array}$ & $\begin{array}{l}10.3 \\
\text { N.D. }\end{array}$ & $\begin{array}{l}586 \\
448\end{array}$ & $\begin{array}{l}8.0 \\
8.2\end{array}$ & $\begin{array}{l}1899 \\
1808\end{array}$ & $\begin{array}{l}\text { B. } 6 \\
\text { 8. } 1\end{array}$ & $\begin{array}{l}783 \\
739\end{array}$ & $\begin{array}{l}937 \\
929\end{array}$ & $\begin{array}{l}3.2 \\
2.7\end{array}$ & $\begin{array}{l}5.0 \\
4.0\end{array}$ \\
\hline$"$ & $\rightarrow$ & $"$ & $"$ & $\begin{array}{l}275 \\
218\end{array}$ & $\begin{array}{l}5.4 \\
3.7\end{array}$ & $\begin{array}{l}472 \\
462\end{array}$ & $\begin{array}{l}3.3 \\
7.5\end{array}$ & $\begin{array}{r}1596 \\
--\end{array}$ & $\begin{array}{l}4.8 \\
--2\end{array}$ & $\begin{array}{l}882 \\
872\end{array}$ & $\begin{array}{l}1034 \\
1020\end{array}$ & $\begin{array}{l}1.6 \\
1.4\end{array}$ & $\begin{array}{l}3.0 \\
7.0\end{array}$ \\
\hline$"$ & $"$ & --- & $"$ & $\begin{array}{l}172 \\
123\end{array}$ & $\begin{array}{l}9.2 \\
9.6\end{array}$ & $\begin{array}{l}519 \\
452\end{array}$ & $\begin{array}{l}6.3 \\
7.1\end{array}$ & $\begin{array}{l}1874 \\
1693\end{array}$ & $\begin{array}{l}5.4 \\
9.9\end{array}$ & $\begin{array}{l}787 \\
783\end{array}$ & $\begin{array}{l}980 \\
976\end{array}$ & $\begin{array}{l}3.7 \\
3.5\end{array}$ & $\begin{array}{l}6.0 \\
8.0\end{array}$ \\
\hline$*$ & $"$ & $"$ & $\cdots$ & $\begin{array}{l}123 \\
103\end{array}$ & $\begin{array}{l}13.5 \\
12.5\end{array}$ & $\begin{array}{l}562 \\
309\end{array}$ & $\begin{array}{l}9.4 \\
6.9\end{array}$ & $\begin{array}{l}1579 \\
1346\end{array}$ & $\begin{array}{l}7.5 \\
5.4\end{array}$ & $\begin{array}{l}689 \\
677\end{array}$ & $\begin{array}{r}994 \\
1020\end{array}$ & $\begin{array}{l}7.3 \\
6.8\end{array}$ & $\begin{array}{l}9.0 \\
8.0\end{array}$ \\
\hline$"$ & "r & $-\cdots$ & $\ldots$ & $\begin{array}{r}125 \\
71\end{array}$ & $\begin{array}{l}10.6 \\
\text { N.D. }\end{array}$ & $\begin{array}{l}487 \\
474\end{array}$ & $\begin{array}{l}7.4 \\
7.0\end{array}$ & $\begin{array}{r}1722 \\
--\end{array}$ & 5.3 & $\begin{array}{l}648 \\
655\end{array}$ & $\begin{array}{l}970 \\
923\end{array}$ & $\begin{array}{r}10.2 \\
8.2\end{array}$ & $\begin{array}{l}15.0 \\
12.0\end{array}$ \\
\hline
\end{tabular}


heat treatment to solution treatment and primary ageing (6h/ $1000^{\circ} \mathrm{C}$ ), i.e. omitting the $24 \mathrm{~h} / 900^{\circ} \mathrm{C}$ and $16 \mathrm{~h} / 700^{\circ} \mathrm{C}$ stages, reduced proof stress but only marginally affected longertime stress-rupture life and greatly increased tensile ductility (Table 2). It seems that a simple solution treatment + primary age should be considered for applications not requiring the highest proof stress and short-time stress-rupture properties.

$$
\text { Secondary Ageing }
$$

Omitting the $24 \mathrm{~h} / 900^{\circ} \mathrm{C}$ age from the 4 -stage treatment had little effect on stress-rupture and tensile properties (Table 2), whereas omitting the $16 \mathrm{~h} / 700^{\circ} \mathrm{C}$ age reduced stressrupture life, particularly at higher stresses, and proof stress but increased tensile ductility. Hence the $900^{\circ} \mathrm{C}$ age seems to contribute least benefit to IN -939 , whereas secondary $\gamma^{\prime}$ precipitated during the $700^{\circ} \mathrm{C}$ age adds to the hardening, increases proof stress and, in consequence, reduces ductility.

To explore secondary ageing further, tensile properties were determined on $\mathrm{IN}-939$ heat treated for $4 \mathrm{~h} / 1160^{\circ} \mathrm{C}+6 \mathrm{~h} /$ $1000^{\circ} \mathrm{C}$ and additionally aged for 16 hours at temperatures between $600^{\circ} \mathrm{C}$ and $900^{\circ} \mathrm{C}$. The variation of room-temperature proof stress with temperature of the second age (Figure 1) maps out the temperature range over which secondary $\gamma^{\prime}$ precipitates. A $180 \mathrm{C}^{\circ}$ difference between the temperatures of primary and secondary ageing is needed to achieve maximum additional hardening, and secondary strengthening does not occur at $850^{\circ} \mathrm{C}$ or above. This conclusion is consistent with the observation that the secondary $\gamma^{\prime}$ precipitate, formed in the final age of the 4-stage treatment, redissolves within 100 hours at $816^{\circ} \mathrm{C}$ or 24 hours at $870^{\circ} \mathrm{C}(6)$.

$$
\begin{aligned}
& \text { Properties of IN }-939 \text { Heat Treated for } \\
& 4 \mathrm{~h} / 1160^{\circ} \mathrm{C}+6 \mathrm{~h} / 1000^{\circ} \mathrm{C}
\end{aligned}
$$

For rotating blades requiring high strength in the blade root, where temperature is below $600^{\circ} \mathrm{C}$ and secondary ageing in service is unlikely, a heat treatment which includes a secondary age will be needed to develop adequate tensile strength. However, for vanes traditionally cast in cobaltbase alloys, which do not have the high tensile strength of $\gamma^{\prime}$ harclened nickel-base superalloys, the simple $4 \mathrm{~h} / 1160^{\circ} \mathrm{C}+$ $6 \mathrm{~h} / 1000^{\circ} \mathrm{C}$ treatment should be adequate. The good ductility provided by that treatment should also prove beneficial in adjusting castings after heat treatment and repair welding. In view of the interest shown in replacing high-cost cobalt 
alloys by IN-939 in some stator vanes, additional data have been determined on IN-939 given this cheap two-stage treatment.

Figure 2 compares the stress-rupture properties of IN-939 given the two- and four-stage heat treatments. As already noted, 100 hours at $816^{\circ} \mathrm{C}$ or 24 hours at $870^{\circ} \mathrm{C}$ is sufficient to dissolve any secondary $\gamma^{\prime}$ precipitate at $700^{\circ} \mathrm{C}$, so it is not surprising that stress-rupture lives for twostage treated material fall on the average property line for four-stage treated IN-939 at temperatures of $870^{\circ} \mathrm{C}$ or above. Both heat treatments give the same stress-rupture life at $816^{\circ} \mathrm{C}$ when lives are above about 150 hours, by when secondary $\gamma^{\prime}$ precipitated at $700^{\circ} \mathrm{C}$ in four-stage-treated material will have dissolved. The two- and four-slage heat-trealed materials are indistinguishable in stress-rupture at $760^{\circ} \mathrm{C}$ and below, presumably because secondary $\gamma^{\prime}$ precipitates in two-stage treated IN-939 during the 16 hour soak at temperature before stress is applied to the stress-rupture specimen.

Temsile data (Figure 3) reveal a double peak in $0.2 \%$ proof stress and UTS after the two-stage treatment. The second peak, at $800^{\circ} \mathrm{C}$, is probably the result of rapid secondary $\gamma^{\prime}$ precipitation and resultant strengthening during the tensile tests.

\section{IFFECT OF COOLING RATE IN HEAT TREATMENT}

Al1 the work reported so far employed air cooling between each stage of the heat treatments, using the standard laboratory procedure of scattering the test-bar blanks on the

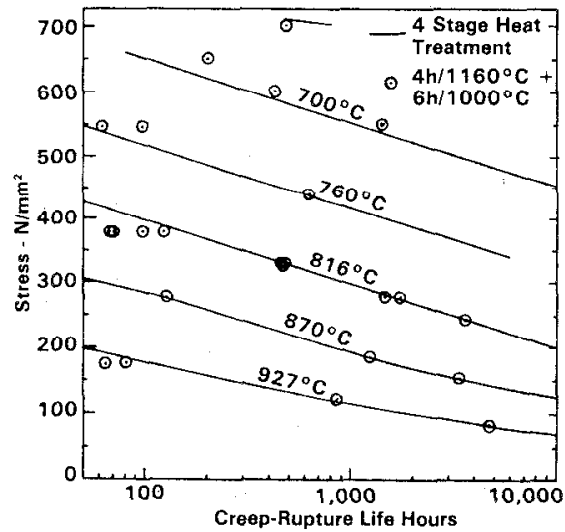

Figure 2. Creep-Rupture Properties of IN-939 Heat Treated $4 \mathrm{~h} / 1160^{\circ} \mathrm{C}+6 \mathrm{~h} / 1000^{\circ} \mathrm{C}$ Air Cooled

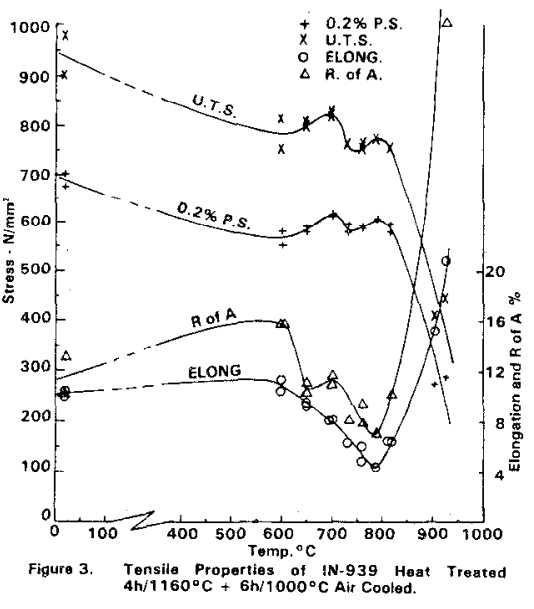


floor or bench. However, cooling rates achieved in commercial vacuum heat-treatment furnaces by rapid gas fan quenching are somewhat slower.

It had been noticed that the primary $\gamma^{\prime}$ is coarser in components vacuum heat treated commercially than in the same components heat treated in the laboratory, because slower cooling after solution treatment allows greater time for the $\gamma^{\prime}$ to grow. Since it is the growth of coarse primary $\gamma^{\prime}$ which appears to give good tensile ductility to material heat treated for $4 \mathrm{~h} / 1160^{\circ} \mathrm{C}+6 \mathrm{~h} / 1000^{\circ} \mathrm{C}$ using air cooling, it seemed possible that growth of primary $\gamma^{\prime}$ on slow cooling from solution troatment might have the same effert and improve the ductility obtainable with the $6 \mathrm{~h} / 1160^{\circ} \mathrm{C}+16 \mathrm{~h} /$ $850^{\circ} \mathrm{C}$ treatment originally used for composition development. To investigate that possibility, carrot-shaped test-piece blanks were given that two stage treatment, cooling from solution treatment at $300 \mathrm{C}^{\circ} / \mathrm{min}$ (air cool), $50 \mathrm{C}^{\circ} / \mathrm{min}$ (in $50 \mathrm{~mm}$ diameter steel cans filled with foundry grog, to simulate a good vacuum-furnace gas fan quench) or $17 \mathrm{C}^{\circ} / \mathrm{min}$ (in refractory brick, to simulate a poor gas fan quench). The slower cooled material had much better tensile ductility, with a proof stress rather below that achievable with the four-stage treatment using air cooling (Table 3).

A marked change in the morphology of the grain-boundary carbide accompanied the reduction in cooling rate (F1gure 4). The thick, continuous carbide film formed on cooling at $300 \mathrm{C}^{\circ} / \mathrm{min}$ was replaced by discrete particles projecting into the grains. The grain-boundary carbide in air-cooled 4-

Jwis

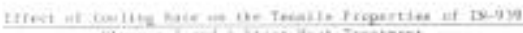

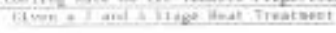

\begin{tabular}{|c|c|c|c|c|c|}
\hline \multirow{3}{*}{$\begin{array}{l}\text { heal } \\
\text { Treatainel }\end{array}$} & \multirow{3}{*}{ 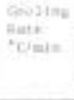 } & \multicolumn{4}{|c|}{$2 w^{*} \mathrm{C}$ 1mentis } \\
\hline & & \multicolumn{2}{|c|}{$\mathrm{N} / \mathrm{w}^{4}$} & \multicolumn{2}{|c|}{2} \\
\hline & & 0,758 & i. 7,5 . & Heas. & C. et $A$. \\
\hline 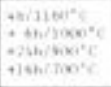 & $+\infty$ & $\begin{array}{l}\text { ano } \\
171\end{array}$ & $\begin{array}{l}250 \\
\text { ans }\end{array}$ & $\begin{array}{l}3.0 \\
3.8\end{array}$ & $\begin{array}{l}9.0 \\
9.0\end{array}$ \\
\hline $\begin{array}{l}\text { thou } 60^{*} c \\
\text { tithinks'r }\end{array}$ & 300 & $\begin{array}{l}3 \times 10 \\
316\end{array}$ & 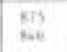 & $\begin{array}{l}0.7 \\
0.3\end{array}$ & $\begin{array}{l}2,8 \\
2,0\end{array}$ \\
\hline " & se & $\begin{array}{l}165 \\
154\end{array}$ & $\begin{array}{l}1006 \\
931\end{array}$ & $\begin{array}{l}\text { 6.S } \\
\text { a.h }\end{array}$ & $\frac{9.8}{1.2}$ \\
\hline$"$ & 31 & $\begin{array}{l}101 \\
095\end{array}$ & $\begin{array}{l}1017 \\
1001\end{array}$ & 3.1 & $\begin{array}{c}8.0 \\
11.4\end{array}$ \\
\hline
\end{tabular}

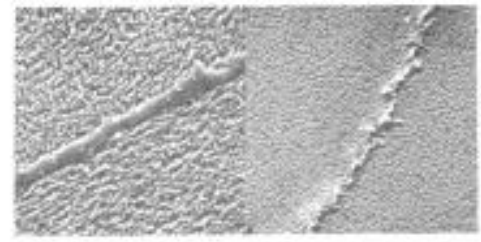

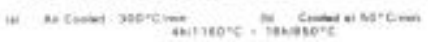

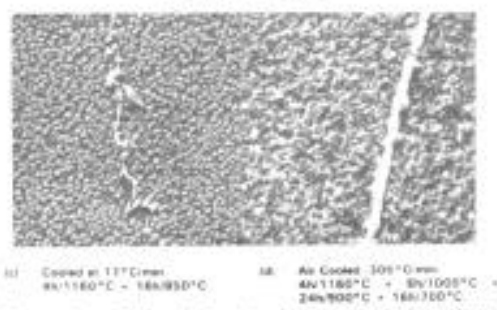

Figua 4. Flfect of Cooling Hate on Grain Boundary Structure of iN 939 
stage treated material (Figure 4d) has an intermediate morphology, consistent with the intermediate ductility in that condition of heat treatment, although no doubt $\gamma^{\prime}$ size also has an effect.

Since proof stress of the slow-cooled two-stage treated material is lower than that of air-cooled four-stage treated alloy, the shorter time stress-rupture properties at intermediate temperature would be expected to be similarly lower. That is confirmed by results to date (Figure 5), which nevertheless show a trend for the two-stage properties to match those of the four stage material in longer times probably in 10,000 hours at $760^{\circ} \mathrm{C}$ and $816^{\circ} \mathrm{C}$, in 1,000 hours at $870^{\circ} \mathrm{C}$ and in 250 hours at $900^{\circ} \mathrm{C}$. Tests are planned to check the properties of slow-cooled two-stage treated material out to 10,000 hours, although some European companies have already adopted the heat treatment for vanes.

Tens1le tests on material heat treated for $4 \mathrm{~h} / 1160^{\circ} \mathrm{C}+$ $16 \mathrm{~h} / 700,750,800$ or $850^{\circ} \mathrm{C}$ with cooling at $50 \mathrm{C}^{\circ} / \mathrm{min}$ showed that ageing at $750^{\circ} \mathrm{C}$ rather than $850^{\circ} \mathrm{C}$ provides proof stress slightly higher than achievable with the 4-stage treatment using air cooling, together with at least as good ductility. Stress-rupture tests are now needed to determine whether this is the alternative cheaper heat treatment, for rotating blades, which the author has been seeking for some time:

\section{WELDABILTTY OF IN-939}

For IN-939 to be a satisfactory substitute for cobalt alloys in vanes, the alloy must possess adequate repair weldability. It was expected that IN-939 would be as unweldable as IN-738LC, but simple tests with cast matching filler rods revealed that smali and large scrap vanes can

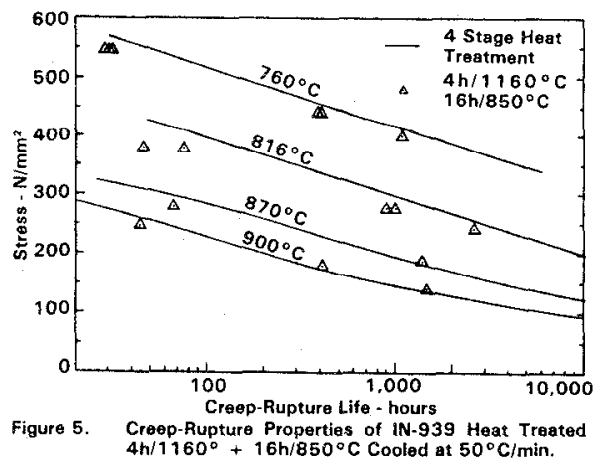

Figure 5. Creep-Rupture Properties of iN-939 Heat Treated $4 \mathrm{~h} / 1160^{\circ}+16 \mathrm{~h} / 850^{\circ} \mathrm{C}$ Cooled at $50^{\circ} \mathrm{C} / \mathrm{min}$.
TABLE 4

EEfect on the Tetatile Dulitility of Ill-939 at $788^{\circ} \mathrm{C}\left(1450^{\circ} \mathrm{F}\right)$ of a Pre-Weld Heat Treacment?

\begin{tabular}{|c|c|c|c|c|c|}
\hline \multicolumn{2}{|c|}{ Heat Treataen $t$} & \multicolumn{4}{|c|}{ Tensile- $788^{\circ} \mathrm{C}\left(1450^{\circ} \mathrm{F}\right)$} \\
\hline \multirow{2}{*}{$\begin{array}{c}\text { Time } \\
h\end{array}$} & \multirow{2}{*}{$\begin{array}{l}\text { Temp. } \\
{ }^{\circ} \mathrm{C}\end{array}$} & \multicolumn{2}{|c|}{$\mathrm{N} / \mathrm{mm}^{2}$} & \multicolumn{2}{|c|}{$z$} \\
\hline & & $0.2 \% \mathrm{PS}$ & ๒.T.S. & Elong. & R. of $A$. \\
\hline 4 & 1038 & 621 & 806 & 7.7 & 19.5 \\
\hline 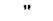 & 1052 & 641 & 856 & 7.8 & 15.9 \\
\hline " & 1066 & 621 & 825 & 8.5 & 20.3 \\
\hline " & 1080 & 593 & 833 & 8.8 & 11.6 \\
\hline$"$ & 1093 & 597 & 826 & 9.4 & 16,0 \\
\hline 20 & 1038 & 640 & 843 & 8.0 & 16.7 \\
\hline & 1052 & 604 & 809 & 13.0 & 26.5 \\
\hline$"$ & 1066 & 624 & 865 & 7.5 & 12.3 \\
\hline$"$ & 1080 & 612 & 828 & 7.9 & 23.8 \\
\hline & 1093 & 607 & 833 & 9.3 & N. D. \\
\hline
\end{tabular}

* As-cast carrot shaped test-bar blanks heat treated in foundry grog in 2 in 0 . D. ar $1 \mathrm{~d}$ ateel can to give a cooling tate of $50^{\circ} \mathrm{C}\left(90^{\circ} \mathrm{F}\right) / \mathrm{mr} \mathrm{n}$. 
be repair welded and are crack free when redressed to size and dye penetrant tested (7). In addition, $12 \mathrm{~mm}$ thick cast plates have been successfully butt-welded together, using a double-V joint preparation, and $80 \%$ joint efficiency was obtained on a creep-rupture test-piece cut out across the weld. For the repair of very large vane segments and large fabrications, pre-weld heat treatments may be found helpful. For material given the suggested heat treatment for vanes of $4 \mathrm{~h} / 1160^{\circ} \mathrm{C}+6 \mathrm{~h} / 1000^{\circ} \mathrm{C}$, the minimum tensile ductility was found to occur at $788^{\circ} \mathrm{C}$ (Figure 3). The ductility at that temperature was much improved by overageing in the range of temperature in which $\boldsymbol{\eta}$-phase precipitates $\left(1038-1093^{\circ} \mathrm{C}\right)$. A $4 \mathrm{~h}$ or $2 \mathrm{Oh}$ age at $1093^{\circ} \mathrm{C}$, followed by cooling at $50 \mathrm{C}^{\circ} / \mathrm{min}$, attained an elongation of over $9 \%$ (Table 4 ) compared with $4.5 \%$ for material treated for $4 \mathrm{~h} / 1160^{\circ} \mathrm{C}+6 \mathrm{~h} / 1000^{\circ} \mathrm{C}$ (air cooled). Further work on welding of IN-939 is continuing, at the Inco Research and Development Centre, Sterling Forest.

\section{DIRECTIONAL SOLIDIFICATION}

Although IN-939 was originally developed as a conventionally cast (C-C) alloy, creep-rupture properties have been found to benefit from directional solidification (DS). When CC and DS materials were compared using the 4stage heat treatment, this benefit was evident only at the higher temperatures $\left(870^{\circ}\right.$ and $927^{\circ} \mathrm{C}$ ) and at times in excess of $\sim 600 \mathrm{~h}$ at $816^{\circ} \mathrm{C}(8)$. At $760^{\circ} \mathrm{C}$, the DS material gave inferior lives to those of the $\mathrm{C}-\mathrm{C}$ material. These surpising results were attributed to the extremely high ductility of the DS material. Since the 4 stage treatment was developed to produce greater ductility, which

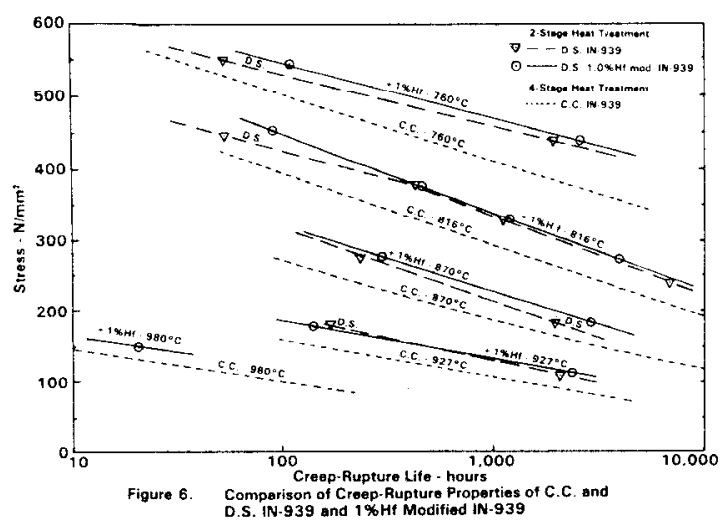


is not necessary for DS material, the tests were repeated with DS material heat treated for $4 \mathrm{~h} / 1160^{\circ} \mathrm{C}+16 \mathrm{~h} / 850^{\circ} \mathrm{C}$ (air cooled). Benefit was then obtained from directional solidification at all test times and temperatures, including short lives at $816^{\circ} \mathrm{C}$ and $760^{\circ} \mathrm{C}$ (Figure 6). Hafnium additions with slight reductions in $\mathrm{Nb}, \mathrm{Ta}$ and $\mathrm{W}$ contents produced further benefits, $1 \% \mathrm{Hf}$ appearing to be the best in the combinations tested (Figure 6).

\section{REFERENCES}

(1) S.W.K. Shaw, "IN-939: A Corrosion-Resistant Alloy for Industrial and Marine Turbine Blades", Metal Progress, March 1979, p.47.

(2) S.W.K. Shaw, "Nicke1-Chromium-Cobalt Alloys", U.S. Patent 4039330.

(3) Ch. Just, P. Huber, R. Bauer, "Evaluation of a New Corrosion Resistant Alloy for Gas Turbine Blades" . 13th Int. Cong. on Combustion Engines, Vienna 1979, Paper GT. 34 .

(4) S.W.K. Shaw, "Heat Treatment of Nicke1-Chromium-Cobalt Base Alloys", U.S. Patent 3898109.

(5) P.A. Beaven, K.M. Delargy, M.K. Miller and G.D.W. Smith, " Combined TEM, FIM Atom Probe Analysis of a Nicke1-Base Superalloy". Proc. Int. Microscopy Congress, Toronto, 1978.

(6) K.M. Delargy, Private Communication 1978.

(7) D.J. Heath, "Weld Repairs in IN-939 Castings", Inco Europe pamphlet, 1979.

(8) S.W.K. Shaw, H.F. Merrick, E.S. Nichols and K.A. Green, "Directional Solidification of $22.5 \%$ Chromium NickelBase Alloys" . 4th Conf. Gas Turbine Materials in the Marine Environment, Annapolis, June 1979. 